\title{
E' LECITO AI POETI ALTERAR LE FAVOLE: THE STORY OF DIDO ACCORDING TO GIOVAN BATTISTA BUSENELLO
}

\author{
ALESSIA MARIA SCALERA \\ Università degli studi di Bari 'Aldo Moro' \\ alessia.scalera@uniba.it \\ ORCID: 0000-0002-7393-0378
}

\section{ABSTRACT}

The aim of this paper is to analyze the rewriting of Dido's myth by Giovan Battista Busenello, the librettist of the first opera named after the queen of Carthage. The imposing regality of Dido and the highly dramatic tension of the Aeneid are absent in Busenello's libretto. Interestingly, if in the fourth book of the Virgilian poem Dido kills herself with Aeneas' sword, in the final act of the opera she marries Iarbas, king of Gaetulians. Poignantly, in her only aria Dido sings her rejection of Iarbas' advances, instead of her death wish or her sorrow for Aeneas' departure.

The tragic éthos we expect of Dido surfaces in two other characters in the opera, Hecuba and Cassandra, specifically through their laments. The basso lines of their laments call to mind the formal archetype at the heart of the famous Dido's lament, Dido's aria in Dido and Eneas, composed by Henry Purcell forty-eight years after the Didone. In that way, Hecuba and Cassandra constitute the actual tragic characters in the Didone, while, conversely, Dido is granted a happy ending, a deviation from the source just as peculiar as its author.

KEYWORDS: Dido, opera, Busenello, Virgil, Cavalli.

\section{E' LECITO AI POETI ALTERAR LE FAVOLE: LA HISTORIA DE DIDO SEGÚN GIOVAN BATTISTA BUSENELLO}

\section{RESUMEN}

El objetivo de este trabajo es analizar la reescritura del mito de Dido por Giovan Battista Busenello, libretista de la primera ópera que lleva el nombre de la reina de Cartago. La imponente realeza de Dido y la dramática tensión de la Eneida están ausentes en el libreto de Busenello. Curiosamente, si en el cuarto libro del poema virgiliano Dido se suicida con la espada de Eneas, en el acto final de la ópera se casa con Iarbas, el rey de los gaetulianos. De forma conmovedora, Dido canta en su única aria su rechazo a los avances de Iarbas, en lugar de su deseo de muerte o su dolor por la partida de Eneas.

El éthos trágico que esperamos de Dido surge en otros dos personajes de la ópera, Hécuba y Cassandra, a través de sus lamentos. Las líneas de bajo de sus lamentos recuerdan el arquetipo formal en el corazón del famoso lamento de Dido, el aria de Dido en Dido y Eneas, compuesto por Henry Purcell cuarenta y ocho años después del Didone. De esa manera, Hécuba y Cassandra constituyen los verdaderos personajes trágicos de Didone, mientras que, a la inversa, a Dido se le concede un final feliz, una desviación de la fuente tan peculiar como su autor.

PALABRAS CLAVE: Dido, ópera, Busenello, Virgilio, Cavalli. 


\section{SOCIAL AND CULTURAL CONTEXT}

Dido appears for the first time on the Italian and European opera scene in the homonymous melodrama, with music by Francesco Cavalli and libretto by Giovanni Francesco Busenello; the Didone was premiered at the San Cassiano Theater in Venice in $1641 .{ }^{1}$

Until 1637, when the first public theater was opened in Venice, operas were mainly performed in courtly or academic feasts, or they could take place in patrician manors: opera was therefore characterized by exceptionality and unrepeatability. Within a few years after the opening of San Cassiano theatre, five more opera theaters were opened in Venice: the San Moisè (1639), the SS. Giovanni and Paolo (1639), the Novissimo (1641), the Sant'Apollinare (1651), and the San Luca or San Salvador (1661).

The proliferation of public opera theaters in Venice set a new direction for the operatic activity: the entrepreneurial vision of opera required a precise organization, a solid economic structure, consistent and regular productions and, most important, it needed continuously new repertoire.

The singer's and the composer's social status underwent a remarkable change: in Rome as well as in Naples they were paid for their regular service (e.g. in the Pope's chapels or in Roman churches) and received donations - not a salary - for extra services; there was no professional specialization for them. Singers and composers in Venice, on the other hand, were professionals under contract, therefore interested in achieving a competitive level of their performance in view of future earnings. In Venice, although the ruling class owned the theaters ${ }^{2}$ and ensured the continuity of the company by enlarging the number of boxes, the real foundation of the theatrical economy, the higher number of theatres and noble families guaranteed competition and high artistic quality of the performances, which still had to be in the public's taste. The first Venetian librettists, including Giovanni Francesco Busenello, were on one side under a sort of patronage, on the other side they depended on the impresario's contingent economic situation: almost all noble or wealthy families were promoters of the first public performances and they reserved the writing of libretti as a literary hobby.

\subsection{The story of Dido, variations on a theme}

We owe Dido's debut on the Italian operatic stage to two well-known personalities of the seventeenth century musical scene: the librettist, Giovanni

\footnotetext{
${ }^{1}$ Cf. Ivanovich (1681: 433).

2 Sometimes the theatre belonged to a noble family, either as in the case of the SS. Giovanni and Paolo theatre, owned by the Grimani family; in most cases they participated to their management, associated with an impresario, or as financiers.
} 
Francesco Busenello, ${ }^{3}$ was a member of the Accademia degli Incogniti, a group of maverick intellectuals; the composer, Francesco Cavalli, was one of the most prominent opera managers in Venice. ${ }^{4}$

The fact that one of the first operas in the European musical scene is named after the Carthaginian queen is a clear proof of the millennial fortune of that mythological figure; the first mention of Dido's story occurs in a fragment of the Sicilian historian Timaeus, ${ }^{5}$ in which Elissa/Dido appears as a paradigm of conjugal fidelity and chastity. The story as told by Timaeus differs from the one by Dante, who portrayed the woman in hell among the lustful ones with Semiramis, Cleopatra and Elena, paying the eternal chastise for not resisting to unfaithful passion (Inf. V, 61-62 "L'altra è colei che s'ancise amorosa, / e ruppe fede al cener di Sicheo"). Anyway, Dante could not have had any other destiny for Dido, considering that his guide during his mystic journey was Virgil himself. The historical version, which exalts the utmost virtue for a married woman, is in fact reworked and overthrown by Virgil: in his interpretation, the queen of Carthage is subjugated by the desperate love for Aeneas and, after being abandoned, commits suicide by throwing herself on his sword. However, Virgil had probably in mind Naevius' version of Dido's story in his Bellum Poenicum, which could have linked the foundations of Rome and Carthage. Indeed, Naevius' influence is uncertain, given the lack of explicit references in the Bellum Poenicum surviving fragments. Anyway, in some late epigrams, Dido complains with Virgil rather than with Naevius, for compromising her morality in his version of the legend. ${ }^{6}$

Virgil's "interpolation" provides Busenello with the opportunity to justify his own re-thinking of the fabula, in which the Queen of Carthage, put aside her husband's memory and now abandoned by Aeneas, married Iarbas, the king of Gaetulians. In the argumentum preceding the 1651 libretto, in fact, Busenello writes:

E se fu anacronismo famoso in Virgilio che Didone, non per Sicheo suo marito, ma per Enea, perdesse la vita, potranno tollerare i grandi ingegni, che qui segua un matrimonio diverso e dalle favole, e dalle istorie. Chi scrive soddisfa al genio, e per schifare il fine tragico della morte di Didone si è introdotto l'accasamento predetto con Iarba. Qui non occorre rammemorare agl'uomini intendenti come i poeti migliori abbiano rappresentate le cose a modo loro, sono aperti i libri, e non è forestiera in questo mondo la erudizione. Vivete felici.

\footnotetext{
${ }^{3}$ Busenello's first book of literary works was named Delle ore ociose and contained several librettos that belong to classics: Gli amori di Apollo e Dafne, La Didone, L'Incoronazione di Poppea, La Prosperità di Giulio Cesare dittatore; cf. Lattarico (2006: 8-9) and Decroisette (1995: 63). For further details on Giovan Francesco Busenello, see Bonomi-Buroni (2010: 13-46).

${ }^{4}$ The Dido myth had a great fortune not only in literature, but also in art and music: $c f$. Kailuweit (2005).

${ }^{5}$ FGrHist F 82 Jacoby.

${ }^{6}$ Cf. AP 16, 151, 5-6; Epigrammata Bobiensia 45 Speyer.
} 
As a member of the Accademia degli Incogniti, and oblivious to any dogmatic restriction, Busenello does not merely bring to the scene an extensive and complex epic story in the form of opera in three acts, ${ }^{7}$ but transforms Dido's Virgilian tragedy into a true happy ending tragicomedy, crowned by a marriage so different from ancient tales to be still astonishing today. ${ }^{8}$

Therefore, even if both Virgil and Busenello largely change the story, the librettist intervenes on the Virgilian version in a particularly invasive way, because until that time Dido's tale used to have a tragic epilogue, the point of convergence of the two variants of the myth.

Of course, some modifications are caused by the different genre. On stage, and in particular in opera, we cannot find a narrator's voiceover, which is very much present in epic, so there are no character comments and descriptive moments. On the other hand, on the stage the attention is all focused on the characters, on their actions, gesture, and voices. Lastly, we have to consider the setting design and the music, which sometimes can replace an actor's speech or a description. ${ }^{9}$

Busenello's interventions mostly consist of extensions and additions to the story in first four books of the Aeneid: in particular, it is important to underline that several original parts are comic and sarcastic, such as Sinon speech in Act 1 , scene 8 , and the scenes that show Iarbas comically in love (e.g. Act 3, scene 2). Of course, we can find serious inserts: the dialogue between Creusa, Ascanius and Aeneas (Act 1, scene 1), the episode in which Ascanius shows his will to fight in war but is stopped by Anchises (Act 1, scene 2), the debate between Iarbas declaring his love and Dido refusing it (Act 2, scenes 1-2), the detail of Anchises made prisoner in Carthage (Act 2, scene 9) and the focus on Iarbas's love that leads him to madness. In only three cases the model is been modified and totally changed: in Act 1, scene 3 Coroebus throws himself against Pyrrhus in order to protect Cassandra and is killed by him, while in the Aeneid he dies in battle with many other soldiers, killed by Peneleos (Aen. 2, 424-5); in Act 1, scene 6, Creusa intentionally leaves her husband and her son to come back home, because she wanted to take some jewels; ${ }^{10}$ the last modification is, of course, the happy ending and the final wedding.

\footnotetext{
7 The first act is set in Troy, the second and the third in Carthage and the Mediterranean.

8 This is, for example, E. Rosand's opinion (1990: 60): "His treatment of the Virgilian episode of Dido and Aeneas bows so deeply to modern taste that it is vergent on the absurd: he supplied that quintessentially tragic story with a happy ending". A few years later, in 1997, such motivations led Thomas Hengelbrock, directing the Balthasar-Neumann-Ensemble, to cut off drastically the entire end of the opera by lowering the curtain on a lifeless Dido.

${ }^{9}$ This is the case of Act 2, scene 5, in which the storm that brings Aeneas to Carthage is described by a sinfonia navale, a musical piece almost certainly accompanied by actor's actions, without words.

${ }^{10}$ For further details on the modification of Creusa episode, see Scalera (2017: 146-151).
} 


\section{DIDO'S HAPPY ENDING: DIDONE ACT III, SCENES 11-12}

Although the striking Virgilian episode of Dido's death ${ }^{11}$ is not completely ignored in the Busenello's libretto, it does not constitute the very ending of the opera. This main, big modification is anticipated at the beginning of the entire opera: Iris, the character that helps Dido to die at the end of the fourth book of the Aeneid (4,693-5), is the protagonist of the prologue of the opera in Act 1 and explains to the public the initial situation of the drama. The goddess shows the result of the Troyan war, taking the role that belonged to Hector, Pantous, Venus and Aeneas in the Aeneid. ${ }^{12}$

In act 3, scene 11, the emotional condition of Dido is expressed by a long lament in common time (4/4) in the tonal area of D. At the beginning of the scene, Dido's suicidal purpose already emerges from the mention of the sword ("porgetemi la spada / del semideo troiano") and from the invitation to maids and servants to leave ("ritiratevi tutte, o fide ancelle; / appartatevi, o servi"). In the Virgilian ipotext, the queen dismisses Barcen, on the pretext of summoning Anna (Aen. 4, 634-640), and takes out the sword only after the woman has turned away (Aen. 4, 646-647).

In this scene Cavalli privileges the discursive linearity of the text, without giving particular emphasis to single words or lines: for this reason it is significant that a single line: "Io regina, io Didone?" is repeated twice on a progression of four sounds that emphasizes emotional tension. The answers to the two questions, arranged in a chiastic scheme ("né Didon, né regina / io son più"), point out the deep trouble of the queen: already surrendered to the passion for Aeneas and abandoned by him, now she feels "vilipesa dai vivi, / minacciata dai morti, / ludibrio uguale agl'uomini, e all'ombre".

Like the Virgilian one, the Busenellian Dido seems sensitive to the repercussions of her 'betrayal' of her royal dignity: if in Aeneid she lists her feats to decisively reaffirm her integrity before dying (Aen. 4, 655-656: urbem praeclaram statui, mea moenia vidi, / ulta virum, poenas inimico a fratre recepi), in the opera the queen complains because she lost her regal dignity and worries that her subjects will look upon her as the vile concubine of Aeneas. The two different attitudes also affect the vision of her soul after her death: Busenellian Dido speaks about her infamous soul and feels that she will always suffer for her mistakes ("fosser pur anco / le genti senza lingua, / le penne senza inchiostri, / muta la fama"). On the contrary, the Virgilian heroin, in her proud re-affirmation of his dignity, sees his soul proudly going under the earth (Aen. 4, 654: et nunc magna mei sub terras ibit imago).

Another difference concerns the value of Dido's death: for the Virgilian one, death will restore her to her queen role, but it will not avenge her (Aen. 4, 659:

\footnotetext{
${ }^{11}$ For a detailed comment of the last episode of the fourth book of the Aeneid, see Pease (1935 ad loc).

${ }^{12}$ Estefanía (2010: 54).
} 
moriemur inultae!). It is the personal redemption that moves the Busenellian Dido ("e se me stessa offesi / or vendico me stessa").

Dido speaks to the sword, which she turns into the heart with firm determination. Unlike the Virgilian model, she still spends benevolent words for Aeneas, because she still keeps his name in her heart: "no'l punger, no l'offender, ma ferisci / il mio cor solo [...] il bel nome di Enea, / per cui finir convengo i giorni afflitti / vada impunito pur de' suoi delitti". Virgilian Dido's words, however, are very different: the heroin, in fact, throws himself on the sword after cursing Aeneas in Aen. 4, 661-662, hauriat hunc oculis ignem crudelis ab alto / Dardanus et nostrae secum ferat omina mortis.

The Virgilian description of suicide, with its realistic and cruel details (Aen. 4, 663-665), is reflected in the words used by Busenello's Dido to wish her death ("nella strage mia / sgorghi il sangue, esca il fiato / resti ogni membro lacerato, e offeso"); a fleeting nod to Carthage ("Cartagine ti lascio") fits into the triple apostrophes to the sword ("ferro passami il core [...] spada vanne con l'elsa e'l pomo in terra [...] e tu punta cortese..."), in which the queen speaks to an ever smaller part of the weapon. Only in the end of the scene, the Busenellian Dido calls Aeneas impious, as Iuno had already done in the fourth scene of the second act ("Enea quel reo, quell'empio").

According to stage directions, at this point Dido would throw herself on the sword, but Iarba prevents her; however, from the first words of Iarba in scene 12 it seems that the queen is actually dead.

The beginning of scene 12, in fact, is a typical tragic finale. After the eloquent words of Dido at the end of scene 11, Iarba thinks that his beloved queen is dead and in front of what is likely to appear on the scene as a dead body reacts like the protagonist of a serious opera. After protesting against gods and their vain promises, ${ }^{13}$ the king of Gaetulians demonstrates the authenticity of his love at first by restraining the impulse of kissing the now lifeless face of Dido ("rapisca il vostro disperato duolo / dall'altar della morte un bacio solo. / No, che se viva fosse / mi negherebbe la mia Dido i baci; / e non debb'io, se ben amor m'ingombra / noiarla in spirito, e fastidirla in ombra"), and then deciding through tears ${ }^{14}$ to reach the woman and kill himself ("ma senza te / non sia mai ver, / ch'io viva un dì; / ciò, che non puote amor, possa la morte").

However, at this point Dido almost resurrects to save the life of those who, judging by her own words, have just rescued her, and to repay Iarba with equal love. Thanks to Dido's unexpected return to life and love for the first time, the two characters are no longer opposed but complementary.

\footnotetext{
${ }^{13}$ His words recall his outburst in Aen. 4, 206-218.

${ }^{14}$ Iarba must have begun to weep from his first words, though he does not point out; however, this detail emerges from the intervention of the king of Gaetulians immediately after he found Didone ("Occhi miei, che stancaste lacrimando / i pianti e l'amarezze, / ora diluviate / del cor mio l'ineffabili dolcezze").
} 
The tonal structure of the second part of the scene is indicative of this change: after the initial short dialogue, characterized by an appropriation by each character of the sonority of the other, as a sort of courtesy, finally Dido and Iarba sing in the same tonal area (C) after a brief invasion of Iarba in the tonal area of D. It is not by chance that the final duet is a triumph of Love: the idea expressed by Iarba ("Son le tue leggi, Amore, / troppo ignote, e profonde, / nel tuo martir maggiore / la gioia si nasconde. / Dalle perdite sai cavar la palma, / dalle procelle tue nasce la calma") is promptly picked up by Dido ("L'àncora della speme, / de' pianti il mare insano / qualor ondeggia, e freme, / non mai si getta invano; / ch'Amor nel mezzo ai casi disperati / i porti più felici ha fabbricati"). Finally, it resounds in the final duet of the opera, trimmed with a remarkable use of sticomitia in the last couple of rhymes.

\section{TRAgiC CHARACTERS IN CAVAlli's DiDONE}

Even if Cavalli's opera is named after Dido, the queen of Carthage does not play a leading role: she actually enters the scene only from Act 2, scene 2 and appears in 9 of 45 scenes. In each act, in fact, the protagonist changes. Aeneas is the main character of the Trojan section in Act 1. Iarba is the protagonist of Act 2, which is opened and closed by solos of the king of Gaetulians, although it also contains the beginning of the affair of Aeneas and Dido. Finally, act 3 contains the actual development of the story in fourth book of the Aeneid, with an unexpected and strange happy ending, in which Iarba is still the protagonist, together with Dido.

The imposing regality of Dido and the highly dramatic tension of the Aeneid are absent in Busenello's libretto. It emerges from the analysis of the arias: in the period of codification of the opera, the first arias were the most 'lyrical' sections that emphasize the personality of the character who sings it. In the Didone, almost every character has its own aria: in Act 1, scene 7 there is the Ecuba's aria (Tremulo spirito), a lament that connotes her as a deeply suffering character. In scene 8, Sinon plays a farcical aria (Ognun millanta riputazione), that points out his behavior. In Act 2, scene 1 there is Iarba's aria (Chi ti diss'io lasso cor mio), which portrays him as the most loving lover. Dido sings her aria in Act 2, scene 2, in which she refuses to love Iarba (Il mio marito già seppellito). The strong religious feeling of Aeneas emerges in his aria, in Act 2, scene 7 (Non fu natural vento a creder mio). Mercury also has its own aria, Act 3, scene 5 (Leva l'ancore, e in alto al gran passaggio), in which he casts out madness from the mind of Iarba.

In addition to the arias, in this opera there are other significant pieces, almost similar to the arias, but not mentioned as 'arias' by Cavalli: in Act 1, scene 4 Cassandra, suffering for Coroebus's death, sings L'alma fiacca svani, and in Act 1, scene 1 Ascanius sings Padre ferma $i$ passi e l'armi. If in these pieces the essences of characters are gathered, then we can deduct that Enea is pius, Iarba is a man in love and Dido is ... frigid. Her role in the drama, rather than protagonist, seems to be the co-protagonist and antagonist of the true protagonist of this 
opera, Iarba, a complex character that frequently switches between tragic and comic. The tragic ethos we expect of Dido, however, surfaces in two other characters, Ecuba and Cassandra, specifically though their laments. This element gains even greater importance if one observes that the story of both characters in the opera is different from the one in the Aeneid. Cassandra sings her lament after Coroebus has died for her, but in Virgil's poem the story of Coroebus is fragmented and shortly treated ${ }^{15}$ and, as we already noticed, his death is not linked to Cassandra, even if he fights insano Cassandrae incensus amore (Aen. 2, 342); moreover, in the Aeneid Cassandra never speaks. Through her lament, Ecuba shows her death desire, because in one night she has lost everything she had, but in the Aeneid, she only appears close to her husband Priamus just before Pyrrhus kills him: her only words are to persuade her old husband not to fight. ${ }^{16}$ For the drama of these two characters, probably Busenello depends on Greek tragedy, in particular from Euripide's The Trojan women. It is almost sure about Ecuba, because her words in Act 1, scene 7 "onde va l'alma mia / cercando oltre le lagrime il tenore / di lamentarsi, mentre in questa notte / in un punto perdei / regno, patria, marito, e figli miei" are very close to the ones she says in the

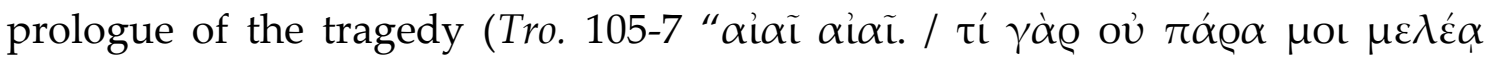

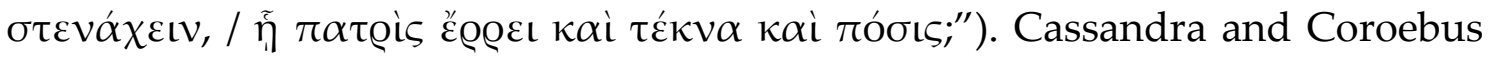
episode can be compared with the final duet of Iarbas and Dido: the two are both original, not linked to a specific ancient (or modern) source, and in both love has repercussions on life, even if in opposite ways. When he realizes that he is dying in Act 1, scene 3, Coroebus says that he has saved Cassandra's life by losing his own. For that reason, she will have to live her and his days ("liberato mio bene / per salvarti la vita / io la vita perdei; / vivi i tuoi giorni, o cara, e vivi i miei"). Cassandra's reaction is to mourn her dead lover and to wait, scared, her own death. In the epilogue of the opera, when Iarbas sees Dido's body he wants to die with her, but for this very reason the Queen of Carthage 'resurrects'. This sort of exchange of lives is well remembered until the opera ends. First, Dido says "da me ricevi in dono / quell che tu mi donasti / La vita a me salvasti, / la vita e la salute a te ridono" and calls Iarbas "preservator della mia vita"; then Iarabs replies "Didon tu preservasti i miei respire, / la vita mia di tua pietade è dono". It is certainly not a case that the last word of the entire opera, that everyone expected to end with a suicide, is "vita".

But there is more: both Cassandra and Ecuba are two profoundly and completely tragic characters who intonate their lament on a descending chromatic tetrachord: the lament of Ecuba, in particular, is based on a simple tetrachord that starts from G; the lament of Cassandra on two adjacent tetrachords starting respectively from D and G.

\footnotetext{
${ }^{15}$ Verg. Aen. 2, 341-346; 403-408; 424-425.

${ }^{16}$ Ibidem, 515-525.
} 
These basso lines call to mind the formal archetype at the heart of the famous Dido's lament, When I am laid in earth, from Dido and Eneas by Henry Purcell, ${ }^{17}$ composed forty-eight years after the Didone. In particular, Purcell's lament employs the same single tetrachord of Hecuba's lament, and its exposition before the beginning of the vocal line, as in Cassandra's lament.

In conclusion we can say that Hecuba and Cassandra are the actual tragic characters in the Didone, while, conversely, Dido is granted a happy ending, a deviation from the source just as peculiar as its author.

\section{BIBLIOGRAPHY}

BONOMI, I. \& BURONI, E. (2010), Il magnifico parassita. Librettisti, libretti e lingua poetica nella storia dell'opera italiana, Milan, FrancoAngeli.

Decroisette, F. (1995), "Réécriture et écriture dans La Didone de Giovan Francesco Busenello", Les langues Néo-latines, 295, 57-86.

DiMundo, R. A. (2013), La Didone virgiliana sulla scena del barocco inglese, Nordhausen, Traugott Bautz.

ESTEFANIA, D. (2010), “La Didone de Busenello: una historia con final feliz”, $C F C(L), 30.1$, 51-76.

IVANOVICH C. (1861), Minerva al tavolino, Venice.

KAILUWEIT, T. (2005), Dido-Didon-Didone. Eine kommentierte Bibliographie zum DidoMythos in Literatur und Musik, Frankfurt, Peter Lang.

LATTARICO, J. F. (2006), “Busenello drammaturgo. Primi appunti per una edizione critica del melodrama", Chroniques italiennes, 77/78 (2/3), 7-26.

Pease A. S. (1935), Publii Vergilii Maronis Aeneidos Liber IV, Cambridge (MA), Harvard University Press.

Rosand, E. (1990), Opera in Seventeenth-Century Venice, Berkeley, Los Angeles and Oxford, University of California.

SCALERA, A. M. (2017), “Le alterne vicende di Didone e Creusa, da Virgilio all’opera lirica veneziana", Vichiana, 54, 139-160.

${ }^{17}$ For further details on Virgilian reception in Purcell's opera, see Dimundo (2013). 
